\title{
Demonstration of Opsonic and Protective Activity of Human Cord Sera against Type III Group B Streptococcus that Are Independent of Type- Specific Antibody ${ }^{1}$
}

\author{
KWANG SIK KIM, CAROL A. WASS, JANE K. HONG, NELYDIA F. CONCEPCION, AND \\ BASCOM F. ANTHONY \\ Department of Pediatrics, Childrens Hospital of Los Angeles, USC School of Medicine, Los Angeles, California \\ 90027 [K.S.K., C.A.W., J.K.H.] and Department of Pediatrics, Harbor-UCLA Medical Center, \\ UCLA School of Medicine, Torrance, California 90509 [N.F.C., B.F.A.]
}

\begin{abstract}
In an effort to further understand the host defense against group B streptococcus (GBS), we examined 71 human cord sera for their content of type III GBS IgG antibody by enzyme-linked immunosorbent assay and correlated the results with opsonic and protective activity against type III GBS. Most cord sera $(67 \%)$ containing $>0.1 \mu \mathrm{g} / \mathrm{ml}$ of type III GBS IgG antibody promoted phagocytosis and killing in vitro and protection against type III GBS in neonatal rats. However, $26 \%$ of cord sera containing $<0.1 \mu \mathrm{g} / \mathrm{ml}$ of type III IgG antibody exhibited similar activity in vitro and in vivo against type III GBS. This opsonic and protective activity was retained in IgG fraction of whole serum, and was not directly associated with complement activity or with fibronectin. Further studies are needed to understand the mechanisms responsible for the opsonic and protective activity of some cord sera against type III GBS that may be independent of antibody to the type-specific polysaccharide antigen. (Pediatr Res 24: 628$632,1988)$
\end{abstract}

\section{Abbreviations}

CFU, colony-forming unit

ELISA, enzyme-linked immunosorbent assay

GBS, group B streptococcus

MEM, minimal essential medium with Earle's balanced salt solution

RABA, radioactive antigen-binding assay

PMN, polymorphonuclear leukocytes

Antibody to type-specific polysaccharides of GBS is important in protecting both humans and experimental animals against GBS diseases (1-5) and it has been suggested that a deficiency of type-specific antibody is a major risk factor for neonatal infection with GBS. Nevertheless, several studies from different geographic areas have demonstrated that most adults lack significant typespecific antibody of the IgG class $(6-10)$ which can cross the placenta, and thus most newborns exposed to GBS are not protected by maternal GBS IgG antibody. A deficiency of type-

Received May 23, 1988; accepted July 25, 1988.

Correspondence and reprint requests Kwang Sik Kim, M.D., Childrens Hospital of Los Angeles, Division of Infectious Diseases, 4650 Sunset Boulevard, Los Angeles, CA 90027.

Supported in part by Research Grants R01-AI24420 and R01-AI14827.

${ }_{1}$ Presented in part at the Annual Meeting of the Society for Pediatric Research and the American Pediatric Society, May 1986, Washington, D.C. specific antibody alone therefore cannot explain the relatively low incidence of systemic GBS infection in neonates after intrapartum exposure to GBS. Approximately 50 to $70 \%$ of neonates exposed to GBS intrapartum become colonized, but only a small fraction $(1-2 \%)$ of those neonates develop invasive GBS disease (11).

In studying the host defense against GBS, we observed opsonic and protective activity against type III GBS in the $\operatorname{IgG}$ fraction of some cord sera that appeared to be independent of typespecific antibody. This report describes those observations.

\section{MATERIALS AND METHODS}

Organism. A type III GBS (strain K79) isolated from the cerebrospinal fluid of a newborn with meningitis (12) was used for in vitro and in vivo studies.

Human cord sera. Human cord sera were collected aseptically from deliveries of healthy, term infants and only those that were free of maternal blood contamination (defined as IgM $<15 \mathrm{mg} /$ dl) were included in this study. Cord blood was allowed to clot at $0^{\circ} \mathrm{C}$ (in ice) and serum was stored in aliquots at $-70^{\circ} \mathrm{C}$ within 60 min of collection to preserve endogenous complement activity. At the time of in vitro and in vivo studies, sera were examined for complement activity by a CH100 assay (Kallestad Laboratories, Austin, TX) and/or CH50 using a standard hemolytic assay (13). Selected sera were also examined for individual complement components by radial immunodiffusion with goat antihuman complement (Nichols Institute, San Juan Capistrano, CA).

Total Ig and type III GBS IgG antibody. Each serum was examined for total IgM concentration by radial immunodiffusion with goat anti-human IgM (Kent Laboratories, Redmond, WA). $\mathrm{IgG}$ antibody against the type III polysaccharide was measured by ELISA $(6,14)$. Selected sera were also examined for total IgG and IgA by radial immunodiffusion with goat anti-human IgG and $\operatorname{IgA}$ (Kent) and for fibronectin concentration by radial immunodiffusion with rabbit anti-human fibronectin (Behring Diagnostics, La Jolla, CA).

In vitro opsonophagocytic assays. The opsonic activity of cord sera was determined by the method described previously (15). Neutrophils from normal adults were isolated by dextran sedimentation followed by Ficoll-Hypaque density centrifugation. Washed neutrophils (approximately $1 \times 10^{6} \mathrm{PMN} / 40 \mu \mathrm{l}$ ) were added to $12 \times 75 \mathrm{~mm}$ sterile polystyrene tubes (Falcon Plastics, Oxnard, CA) along with $10 \mu 1$ of washed logarithmic-phase strain K79 (approximately $\left.2 \times 10^{5} \mathrm{CFU}\right), 10 \mu \mathrm{l}$ of cord sera and $20 \mu \mathrm{l}$ of MEM (GIBCO Laboratories, Santa Clara, CA) in a total 
volume of $80 \mu \mathrm{l}$. The same MEM was used in washing and resuspending the PMN and bacteria. The phagocytic mixture contained a ratio of PMN to bacteria of approximately $5 / 1$. Control tubes lacking either PMN or serum were included in each experiment. The tubes were incubated at $37^{\circ} \mathrm{C}$ with tumbling on a multipurpose rotator (Scientific. Industries, Inc., Springfield, MA). Aliquots $(10 \mu \mathrm{l})$ were taken from each tube at 0 and $1 \mathrm{~h}$, serially diluted 10 -fold in sterile distilled water, and plated on blood agar to determine surviving CFU. Results were expressed as the percentage of bacteria killed: $100-[$ (CFU at 1 $\mathrm{h} / \mathrm{CFU}$ at $0 \mathrm{~h}) \times 100]$.

Separation of $\operatorname{Ig} G$ from whole sera. To determine if the $\mathrm{IgG}$ fraction of cord sera was responsible for opsonic activity, IgG was separated from cord sera by the method of Johnson and Libby (16). Briefly, $250 \mu$ l of whole serum diluted 20 -fold in 0.05 M EDTA buffer, pH 7.0, was passed through a small column (1 $\mathrm{ml}$ bed volume) of quarternary aminoethyl-Sephadex A-50 (Pharmacia Fine Chemical, Piscataway, NJ), which was then eluted with $5 \mathrm{ml}$ of the same buffer. The eluate was concentrated approximately 40 -fold with an ultrafiltration membrane (Diaflo XM 50, Amicon Corp, Lexington, MA), dialyzed against phosphate-buffered saline, $\mathrm{pH} 7.4$, overnight at $4^{\circ} \mathrm{C}$ in cellulose dialysis tubing (mol. wt. cutoff $12,000-14,000$, Spectrapor membrane tubing, Spectrum Medical Industries, Inc., Los Angeles, CA) and used for opsonophagocytic and animal experiments. Opsonophagocytic assays were essentially the same as described previously except that cord serum devoid of both type III IgG antibody and opsonic activity was added as a source of complement because complement activity was undetectable in the IgG fractions separated by QAE-Sephadex. Total levels of IgG, IgM, and IgA were measured simultaneously on whole and fractionated serum.

Animal studies. Outbred, pathogen-free Sprague-Dawley pregnant rats (with timed conception) were purchased from Charles River Breeding Laboratories (Wilmington, MA) and gave birth in our vivarium 5-7 days after arrival. Each adult rat and her pups were housed in a separate, solid polypropylene, opaque cage with a filter hood.

GBS bacteremia was induced in 5-day-old rats as described previously $(15,17,18)$. At 5 days of age, all members of each litter were divided into two groups to receive intraperitoneally $0.1 \mathrm{ml}$ of cord serum with opsonic activity (>80\% killing at $1 \mathrm{~h}$ of incubation) or cord serum with less opsonic activity. Two or three rats from each litter served as controls, receiving $0.1 \mathrm{ml}$ of saline. Within $30 \mathrm{~min}$, animals were inoculated subcutaneously with $1 \times 10^{5}$ CFU of type III GBS strain K79. As shown previously $(15,17,18)$, this inoculum produces nonlethal bacteremia within $18 \mathrm{~h}$ and subsequent death within 5 days in almost $100 \%$ of the animals. A total of $18 \mathrm{~h}$ after bacterial inoculation, $0.1 \mathrm{ml}$ of blood was obtained from each rat for quantitative cultures. Mortality was recorded for 5 days, and postmortem blood cultures were done to confirm GBS infection.

Statistical methods. The odds ratio was used to determine the association between concentrations of type III GBS of IgG antibody and opsonic activity (19). The $\chi^{2}$ (with Yates' correction for small samples) was used to compare the incidence of bacteremia and the mortality rates, and the Student's $t$ test was used to compare the magnitude of bacteremia among groups of animals (20).

\section{RESULTS}

Type III GBS antibody versus opsonic activity. In all, 71 cord sera were examined for type III GBS IgG antilody by ELISA and the results were compared with those of opsonic activity against a type III GBS strain (Fig. 1). Thirty-three cord sera contained $\geq 0.1 \mu \mathrm{g} / \mathrm{ml}$ of type III GBS IgG antibody and 38 cord sera contained $<0.1 \mu \mathrm{g} / \mathrm{ml}$ of type III IgG antibody. When cord sera were examined for total complement activity by $\mathrm{CH} 100$

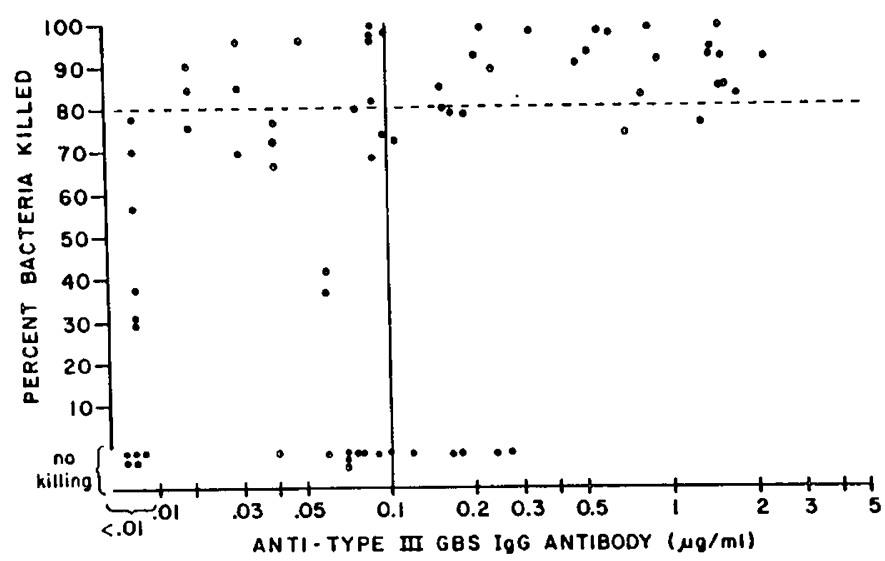

Fig. 1. Comparison of 71 human cord sera for the contents of type III GBS IgG antibody $(\mu \mathrm{g} / \mathrm{ml})$ and opsonic activity (\% bacteria killed after $1 \mathrm{~h}$ of incubation).

assay, the majority of cord sera $(41 / 71$ or $65 \%)$ contained $>70$ $\mathrm{CH} 100 \mathrm{U} / \mathrm{ml}$ (considered normal range). Selected sera with $>70$ $\mathrm{CH} 100 \mathrm{U} / \mathrm{ml}$ were also found to contain $120-180 \mathrm{CH} 50 \mathrm{U} / \mathrm{ml}$ (normal range in our laboratories).

In opsonophagocytic assays, bacterial killing did not occur in control tubes, indicating that phagocytosis and killing of type III GBS organism required both PMN and cord sera. Of the 33 cord sera that contained $\geq 0.1 \mu \mathrm{g} / \mathrm{ml}$ of type III IgG antibody, most $(22 / 23$ or $67 \%)$ were, as expected, highly effective in supporting phagocytosis and $\geq 80 \%$ killing of the original inoculum of strain K79 after $1 \mathrm{~h}$ of incubation. The odds of exhibiting efficient opsonic activity ( $\geq 80 \%$ killing) were 5.6 times greater for cord sera containing $\geq 0.1 \mu \mathrm{g} / \mathrm{ml}$ of type III GBS IgG antibody than for cord sera containing lesser amounts of type III IgG antibody. This odds ratio was significant $(p=0.001)$.

Surprisingly, $10 / 38(26 \%)$ cord sera containing $<0.1 \mu \mathrm{g} / \mathrm{ml}$ of type III GBS IgG antibody were also effective in supporting the killing of $\geq 80 \%$ of the original inoculum. The demonstration of efficient opsonic activity was not directly influenced by $\mathrm{CH} 100$ values. Six $(60 \%)$ of the 10 cord sera containing $<0.1 \mu \mathrm{g} / \mathrm{ml}$ of IgG antibody and exhibiting $\geq 80 \%$ killing contained $>70 \mathrm{CH} 100$ (normal range); whereas $19(68 \%)$ of 28 cord sera with $<0.1 \mu \mathrm{g} /$ ml of antibody and showing $<80 \%$ killing contained $>70 \mathrm{CH} 100$ (normal range). Similarly, reduced opsonic activity of cord sera containing $>0.1 \mu \mathrm{g} / \mathrm{ml}$ of type III IgG antibody was not due to decreases in $\mathrm{CH} 50$ or individual complement components (Table 1).

To examine the significance of these findings further, we studied cord sera with $<0.1 \mu \mathrm{g} / \mathrm{ml}$ of antibody for their protective activity against experimental GBS infection in newborn rats.

Opsonic versus protective activity. First, we evaluated and compared two cord sera (nos. 19 and 23) containing similar amounts of type III GBS IgG antibody but differing in their opsonic activity ( $96 \%$ killing versus no killing, respectively). As summarized in Table 2, these two cord sera contained similar amounts of total IgG, IgM, type III GBS IgG, fibronectin, and $\mathrm{CH} 100$. Table 3 summarizes the incidence and magnitude of bacteremia at $18 \mathrm{~h}$ after subcutaneous inoculation with strain $\mathrm{K} 79$, and overall survival rates in groups of animals receiving cord sera 19 or 23 or saline. After $18 \mathrm{~h}$ of infection, all control animals receiving saline (six of six) were bacteremic. The prevalence of bacteremia at this time was significantly lower $(p<$ 0.01 ) in animals receiving cord sera 19 than in those receiving cord sera 23 . The magnitude of bacteremia at $18 \mathrm{~h}$ was compared among animals with positive blood cultures. Bacterial counts in blood of animals receiving cord sera 19 were significantly lower $(p<0.01)$ than those receiving cord sera 23 or saline. Survival rates over the 5-day period are also summarized in Table 3 ; the overall rate was significantly higher in animals receiving cord 
sera 19 than in those receiving cord sera 23 or saline $\left(\chi^{2}=6.00\right.$ and 7.65 , respectively, $p<0.02$ ).

We next attempted to determine if the opsonic and protective activity of cord sera was related to IgG or non-IgG components. For this study, we used two cord sera (nos. 30 and 31) containing low levels of type III GBS IgG antibody $(0.02$ and $0.03 \mu \mathrm{g} / \mathrm{ml})$, respectively) but exhibiting excellent opsonic activity (90 and $96 \%$ bacterial killing, respectively). As shown in Table $4, \mathrm{IgG}$ separated by QAE-Sephadex yielded equivalent amounts of IgG compared with whole serum and contained no detectable IgM and IgA. Inasmuch as the type III GBS IgG antibody concentrations were very low in whole serum, they were not measured in

Table 1. Comparison of $\mathrm{CH} 50$ and individual complement components between cord sera possessing similar amounts of type III GBS IgG antibody but differing in their opsonic activity

\begin{tabular}{|c|c|c|c|c|}
\hline & \multicolumn{2}{|c|}{ Cord serum } & \multicolumn{2}{|c|}{ Cord serum } \\
\hline & $5 \mathrm{~S}$ & $15 \mathrm{~S}$ & 32 & $13 \mathrm{~S}$ \\
\hline $\begin{array}{l}\text { Type III IgG }(\mu \mathrm{g} / \\
\mathrm{ml})\end{array}$ & 0.23 & 0.21 & 1.77 & 1.6 \\
\hline $\begin{array}{l}\mathrm{CH} 50(\text { normal, } \\
120-180 \mathrm{U} / \mathrm{ml})\end{array}$ & 132 & 156 & 141 & 132 \\
\hline $\begin{array}{l}\text { Clq (normal, 5-8.6 } \\
\text { mg/dl) }\end{array}$ & 3.2 & 3.9 & 3.5 & 3.6 \\
\hline $\begin{array}{l}\text { C2 (normal, 2-3.7 } \\
\text { mg/dl) }\end{array}$ & 1.8 & 2.6 & 2.2 & 2.0 \\
\hline $\begin{array}{l}\text { C5 (normal, 7-16 } \\
\text { mg/dl) }\end{array}$ & 8.9 & 10.9 & 10.9 & 7.9 \\
\hline $\begin{array}{l}\text { C6 (normal, 3.6- } \\
\quad 7.5 \mathrm{mg} / \mathrm{dl} \text { ) }\end{array}$ & 2.7 & 3.1 & 3.0 & 2.4 \\
\hline $\begin{array}{l}\text { C7 (normal, 3.9- } \\
7.8 \mathrm{mg} / \mathrm{dl})\end{array}$ & 5.6 & 7.2 & 8.1 & 6.5 \\
\hline $\begin{array}{l}\text { C8 (normal, } 2.7- \\
6.0 \mathrm{mg} / \mathrm{dl})\end{array}$ & $<2.4$ & $<2.4$ & $<2.4$ & $<2.4$ \\
\hline $\begin{array}{l}\text { C9 (normal, 2.4- } \\
6.9 \mathrm{mg} / \mathrm{dl} \text { ) }\end{array}$ & 1.7 & 2.0 & $<1.7$ & $<1.7$ \\
\hline $\begin{array}{l}\text { Opsonic activity (\% } \\
\text { bacteria killed) }\end{array}$ & No killing & 92 & 60 & 96 \\
\hline
\end{tabular}

Table 2. Comparison of total IgG, IgM, IgA, type III GBS IgG, fibronectin, $\mathrm{CH} 100$, and opsonic activity between cord sera 19 and 23

\begin{tabular}{lcc} 
& Cord serum & Cord serum \\
& 19 & 23 \\
\hline Total IgG $(\mathrm{mg} / \mathrm{dl})$ & 947 & 600 \\
Total IgM $(\mathrm{mg} / \mathrm{dl})$ & 13 & 10.4 \\
Total IgA $(\mathrm{mg} / \mathrm{dl})$ & $<5.6$ & $<5.6$ \\
Type III GBS IgG $(\mu \mathrm{g} / \mathrm{ml})$ & 0.09 & 0.08 \\
Fibronectin $(\mathrm{mg} / \mathrm{dl})$ & 5.5 & 6.1 \\
CH100 $(\mathrm{U} / \mathrm{ml})$ & 71 & 80 \\
Opsonic activity $(\%$ bacteria killed) & 96 & No killing \\
\hline
\end{tabular}

separated IgG preparations. Although cord serum 31 contained $4.6 \mathrm{mg} / \mathrm{dl}$ of fibronectin, fibronectin was not detectable in separated IgG. Opsonophagocytic studies revealed that enhancement of PMN-mediated killing by separated $\mathrm{IgG}$ was similar to that by whole serum (Table 4). Similarly, when separated IgG preparations were evaluated for their protective activity against experimental type III GBS infection compared with whole serum, their protective efficacy was similar, as shown by similar prevalence and magnitude of bacteremia at $18 \mathrm{~h}$ after subcutaneous inoculation with strain $\mathrm{K} 79$ and similar survival rates (Table 5).

\section{DISCUSSION}

Our studies revealed that most cord serum containing significant amounts of type III GBS IgG antibody $(\geq 0.1 \mu \mathrm{g} / \mathrm{ml})$ were, as expected, highly effective in enhancing phagocytosis and killing of type III GBS ( $\geq 80 \%$ killing of the original inoculum). This efficient opsonophagocytic activity was also directly correlated with significantly greater protection against bacteremia and death in newborn rats challenged with a type III GBS strain. However, $26 \%$ of cord sera containing lesser amounts of type III GBS IgG antibody also exhibited efficient opsonophagocytic and protective activity against type III GBS. This activity was independent of total complement activity, as shown by a lack of correlation between $\mathrm{CH} 100 / \mathrm{CH} 50$ values and opsonic activity among cord sera containing similar amounts of type III GBS IgG antibody.

Several studies have shown that IgM monoclonal antibody against type III polysaccharides effectively provides protection against experimental type III GBS infection in neonatal rats and mice $(9,22)$. Campbell et al. (23) have also shown that the opsonophagocytic activities of naturally acquired IgM and IgG antibodies for type III GBS are comparable. A recent report indicated a strikingly high prevalence of IgM antibody to type III GBS compared with IgG antibody in some adult and maternal sera (6). Boyer et al. (24) have shown that development of IgM

Table 4. Total IgG, IgM, IgA, and type III GBS IgG concentrations and opsonic activity in IgG-containing sera separated from cord sera by quartenary aminoethyl-Sephadex in comparison with whole sera

\begin{tabular}{|c|c|c|c|c|}
\hline & \multicolumn{2}{|c|}{ Cord sera 30} & \multicolumn{2}{|c|}{ Cord sera 31} \\
\hline & $\begin{array}{l}\text { Whole } \\
\text { sera }\end{array}$ & $\begin{array}{l}\text { Separated } \\
\text { IgG }\end{array}$ & $\begin{array}{l}\text { Whole } \\
\text { sera }\end{array}$ & $\begin{array}{l}\text { Separated } \\
\text { IgG }\end{array}$ \\
\hline $\operatorname{IgG}(\mathrm{mg} / \mathrm{dl})$ & 950 & 1050 & 870 & 790 \\
\hline $\mathrm{IgM}(\mathrm{mg} / \mathrm{dl})$ & 9.7 & $<4.9$ & 4.9 & $<4.9$ \\
\hline $\operatorname{IgA}(\mathrm{mg} / \mathrm{dl})$ & $<5.6$ & $<5.6$ & $<5.6$ & $<5.6$ \\
\hline $\begin{array}{l}\text { Type III GBS IgG } \\
(\mu \mathrm{g} / \mathrm{ml})\end{array}$ & 0.02 & Not done & 0.03 & Not done \\
\hline $\mathrm{CH} 100$ (units/ml) & 100 & Undetectable & 39 & Undetectable \\
\hline $\begin{array}{l}\text { Opsonic activity } \\
\text { (\% bacteria } \\
\text { killed) }\end{array}$ & 90 & 90 & 99 & 96 \\
\hline
\end{tabular}

Table 3. Incidence and magnitude of bacteremia and overall survival among animals receiving cord sera 19 or 23 or saline

\begin{tabular}{ccccc}
\hline Cord sera & $\begin{array}{c}\text { No. of } \\
\text { animals }\end{array}$ & $\begin{array}{c}\text { No. of animals } \\
\text { with positive } \\
\text { blood cultures }(\%)^{*}\end{array}$ & $\begin{array}{c}\text { Magnitude of bacteremia* } \\
\left(\log _{10} \text { CFU/ml }\right. \\
\text { of blood })\end{array}$ & $\begin{array}{c}\text { Overall } \\
\text { survival (\%) }\end{array}$ \\
\hline 19 & 13 & $2(15 \%) \ddagger$ & $1.35 \pm 0.00$ & $12(92) \S$ \\
23 & 13 & $10(77 \%)$ & $4.91 \pm 1.52$ & $6(46)$ \\
Saline & 6 & $6(100 \%)$ & $5.06 \pm 0.89$ & $1(17)$ \\
\hline
\end{tabular}

${ }^{*}$ A total of $18 \mathrm{~h}$ after infection.

$\uparrow$ Expressed as mean \pm SD.

$\ddagger$ The prevalence of bacteremia was significantly less $\left(\chi^{2}=7.58, p<0.01\right)$ with cord serum 19 than with cord serum 23 .

$\S$ The overall survival rate was significantly greater with cord serum 19 than with cord serum 23 or saline $\left(\chi^{2}=6.00\right.$ and $7.65 ; p<0.02$ and $p<$ 0.01 , respectively). 
Table 5. Incidence and magnitude of bacteremia and overall survival among animals receiving cord sera, separated IgG or saline

\begin{tabular}{|c|c|c|c|c|c|}
\hline Experiment & Sera & $\begin{array}{l}\text { No. of } \\
\text { animals }\end{array}$ & $\begin{array}{c}\text { No. of positive } \\
\text { blood cultures } \\
(\%)^{*}\end{array}$ & $\begin{array}{c}\text { Magnitude of bacteremia* } \dagger \\
\left(\log _{10} \mathrm{CFU} / \mathrm{ml}\right. \\
\text { of blood) }\end{array}$ & Survival \\
\hline \multirow[t]{3}{*}{1} & Cord sera \#30 & 8 & $2(25) \ddagger$ & $1.35 \pm 0.00$ & $7(88)$ \\
\hline & Separated IgG & 8 & $1 \quad(12) \ddagger$ & 1.35 & $7(88)$ \\
\hline & Saline & 8 & $7(88)$ & $3.22 \pm 1.82$ & $4(50)$ \\
\hline \multirow[t]{2}{*}{2} & $\begin{array}{l}\text { Separated IgG } \\
\text { from cord } \\
\text { sera \#31 }\end{array}$ & 9 & 0 & 0 & $9(100)$ \\
\hline & Saline & 6 & $6(100) \S$ & $5.13 \pm 0.96$ & 0 \\
\hline
\end{tabular}

* A total of $18 \mathrm{~h}$ after infection.

$\dagger$ Expressed as means \pm SD. $0.05)$.

$\ddagger$ The prevalence of bacteremia was significantly less with cord sera 30 or separated IgG than with saline $\left(\chi^{2}=4.06\right.$ and 6.25 , respectively, $p<$

$\S$ The prevalence of bacteremia was significantly less $\left(\chi^{2}=11.12, p<0.001\right)$ with separated $\operatorname{IgG}$ than with saline.

specific antibody to type III GBS is age dependent; acquisition of protective levels of IgM antibody to type III GBS $(\geq 0.3 \mu \mathrm{g} /$ $\mathrm{ml}$ ) in infants is observed after 6 months of age (23). These findings suggest that the presence of IgM antibody may in part explain the infrequent occurrence of invasive GBS disease beyond infancy. In the present study, cord sera were selected based on their low total IgM concentrations $(<15 \mathrm{mg} / \mathrm{dl})$. Type III GBS IgM antibody was not measured because, in our previous studies (6), IgM antibody was undetectable in cord sera free of maternal blood contamination. Moreover, IgG separated from whole serum devoid of IgM showed opsonic and protective activity against type III GBS similar to that of whole serum. Therefore, the excellent functional activity of some cord sera containing $<0.1 \mu \mathrm{g} / \mathrm{ml}$ of type III GBS IgG antibody is not likely due to the presence of $\operatorname{IgM}$ antibody.

Other host factors such as fibronectin also did not appear responsible for the functional activity of some cord sera containing insignificant amounts of type III GBS antibody. When two cord sera having similar amounts of type III GBS IgG antibody $(0.08$ and $0.09 \mu \mathrm{g} / \mathrm{ml}$, respectively) as well as fibronectin $(6.1$ and $5.5 \mathrm{mg} / \mathrm{dl}$, respectively) were examined for their opsonic and protective activity, there was a wide disparity between them. Moreover, separated IgG devoid of fibronectin was found to exhibit similar opsonic and protective activity compared to whole serum.

There are obvious difficulties in comparing measurements of specific antibody in different laboratories. We therefore selected 11 cord sera for study of total type III GBS antibody by the radioactive antigen-binding assay (RABA) (25), which presumably measures all isotypes, in the laboratory of Dr. Morven Edwards of Baylor College of Medicine, Houston, TX. There was a strong correlation between the two assays. All but two cord sera containing $<0.1 \mu \mathrm{g} / \mathrm{ml}$ of type III GBS IgG antibody by ELISA were found to have type III GBS antibody $<2 \mu \mathrm{g} / \mathrm{ml}$ by RABA (considered to be low levels of antibody) $(25,26)$. Therefore, these sera clearly contained low concentrations of type III $\mathrm{IgG}$ antibody. Available data do not indicate that differences in opsonic activity are likely due to differences in antibody affinity for type III polysaccharide. This was suggested by similar slopes of optical density values in ELISA for dilutions of cord sera containing similar amounts of type-specific IgG antibody, but differing in their opsonic activity (data not shown). However, it is possible that some opsonic and protective activity of low concentrations of type III IgG antibody in some sera may be due to greater affinity/avidity.

The type III GBS strain K79 used for this study was found to possess $\mathrm{R}$ protein. When cord sera possessing efficient opsonophagocytic activity against strain K79 ( $\geq 80 \%$ killing of the original inoculum) were reexamined after absorption with type III polysaccharides, opsonophagocytic activity was completely abolished against another type III GBS strain without protein antigens, but similar opsonic activity ( $\sim 60 \%$ killing) was present against the R protein-positive strain K 79 (data not shown). These two type III strains with or without $\mathrm{R}$ protein contained similar amounts of sialic acid (data not shown), indicating that differences in opsonophagocytic activity against two type III GBS strains of sera absorbed with type III polysaccharides are not due to differences in sialic acid content. These findings suggest that additional antibody directed against other surface antigens (e.g. $\mathrm{R}$ protein) may possibly be responsible for opsonic activity observed against strain K79 in some cord sera. Linden et al. (27) and Christensen et al. (28) have suggested that R protein antibody may be important in protecting mice against GBS strains possessing $\mathrm{R}$ protein. Additional studies are therefore needed to determine if the opsonic and protective activity that appear to be independent of type-specific GBS antibody may stem from antibodies directed against other surface antigens (e.g. R protein).

We are still far from a complete understanding of the hostmicrobial factors that determine the development of invasive GBS infection in human neonates. However, our observations suggest that the opsonic and protective activity that appears to be independent of type-specific antibody noted in our report may in part account for the relatively low incidence of systemic GBS infection in neonates subsequent to intrapartum exposure to GBS.

Acknowledgments. The authors thank Dr. Morven Edwards of Baylor College of Medicine for measuring the type III GBS antibody concentrations; Dr. Patricia Ferrieri of the University of Minnesota School of Medicine, Minneapolis, and Dr. Jarmila Jelinkova of the Institute of Hygiene and Epidemiology, Praha, Czechoslovakia for typing of type III GBS strains for protein antigens; John Peschetti, R.N. and Sara Alvarez, R.N. for collection of cord blood; and Caroline Rivera for typing the manuscript.

\section{REFERENCES}

1. Lancefield RC, McCarty M, Everly WN 1975 Multiple mouse-protective antibodies directed against group B streptococci. J Exp Med 142:165-179

2. Baker, CJ, Kasper DL 1976 Correlation of maternal antibody deficiency with susceptibility to neonatal group B streptococcal infection. N Engl J Med 294:753-756

3. Hemming VG, Hall RT, Rhodes PG, Shigeoka AO, Hill AR 1976 Assessment of group B streptococcal opsonins in human and rabbit serum by neutrophil chemiluminescence. J Clin Invest 58:1379-1387

4. Fischer GW, Hunter KW, Wilson SR 1982 Modified human immune serum globulin for intravenous administration: in vitro opsonic activity and in vivo protection against group B streptococcal diseases in suckling rats. Acta Paediatr Scand 71:639-644

5. Shigeoka AO, Pincus SH, Rote NS, Hill HR 1984 Protective efficacy of hybridoma type-specific antibody against experimental infection with groupB Streptococcus. J Infect Dis 149:363-372

6. Anthony BF, Concepcion NF, Wass CA, Heiner DC 1984 Immunoglobulin G and $\mathrm{M}$ composition of naturally occurring antibody to type III group $\mathrm{B}$ 
streptococci. Infect Immunol 46:98-104

7. Gotoff SP, Papierniak CK, Klegerman ME, Boyer KM 1984 Quantitation of IgG antibody to the type-specific polysaccharide of group B streptococcus type $1 \mathrm{~b}$ in pregnant women and infected infants. J Pediatr 105:628-630

8. Klegerman ME, Boyer KM, Papierniak CK, Gotoff SP 1983 Estimation of the protective level of human IgG antibody to the type-specific polysaccharide of group B streptococcus type Ia. J Infect Dis 148:648-655

9. Vogel LC, Boyer KM, Gadzala CA, Gotoff SP 1980 Prevalence to type-specific group B streptococcal antibody in pregnant women. J Pediatr 96:1047-1051

10. Gray BM, Dillon HC 1982 Antibody prevalence to group B streptococcus type Ia by ELISA. Program and Abstracts of the 22nd Interscience Conference on Antimicrobial Agents and Chemotherapy American Society for Microbiology, Washington, DC, p 111 (abstr 263)

11. Fischer G, Horton RE, Edelman R 1983 Summary of the National Institutes of Health Workshop on Group B streptoccal infection. J Infect Dis 148:163166

12. Kim KS, Anthony BF 1981 Penicillin tolerance in group B streptococci isolated from infected neonates. J Infect Dis 144:411-419

13. Glovsky MM, Cortes-Haendchen L, Ghekiere L, Alenty A, Williams DL, DiLuzio NR 1983 Effects of particulate-1, 3 glucan on humans, rat and guinea pig complement activity. J Reticuloendothel Soc 33:401-413

14. Anthony BF, Concepcion NF, McGeary SA, Ward JI, Heiner DC, Shapshak $P$, Insel RA 1982 Immunospecificity and quantitation of an enzyme-linked immunosorbent assay for group B streptococcal antibody. J Clin Microbio $16: 350-354$

15. Kim KS, Wass CA, Kang JH, Anthony BF 1986 Functional activities of various preparations of human intravenous immunoglobulin against type III group B Streptococcus. J Infect Dis 153:1092-1097

16. Johnson Jr RB, Libby R 1980 Separation of immunoglobulin M (IgM) essentially free of IgG from serum for use in systems requiring assay of IgM-type antibodies without interence from rheumatoid factor. J Clin Microbiol $12: 451-454$

17. Kim KS 1985 Efficacy of imipenem in experimental group B streptococcal bacteremia and meningitis. Chemotherapy 31:304-309

18. Kim KS 1986 Efficacy of cefmenoxime in experimental group B streptococcal bacteremia and meningitis. J Antimicrob Chemother 17:239-244

19. Fleiss JL 1981 Statistical Methods for Rates and Proportions. John Wiley \& Sons, Inc, New York

20. Colton T 1974 Statistics in medicine. Little, Brown \& Co, Boston

21. Egan ML, Pritchard DG, Dillon Jr HC, Gray BM 1983 Protection of mice from experimental infection with type III group B streptococcus using monoclonal antibodies. J Exp Med 158:1006-1111

22. Shigeoka AO, Jensen CL, Pincus SH, Hill HR 1984 Absolute requirement for complement in monoclonal IgM antibody-mediated protection against experimental infection with type III group B streptococci. J Infect Dis 150:6370

23. Campbell JR, Baker CJ, Metzger TG, Edwards MS 1988 Functional activity of class-specific antibodies to type III, group B streptococcus. Pediatr Res 23:31-34

24. Boyer KM Papierniak CK Klegerman ME, Rauen ME, Gotoff SP 1987 Development of IgM antibody to group B streptococcus (GBS) type III in human infants. Pediatr Res 21:413A(abstr 1436)

25. Edwards MS, Baker CJ, Kasper DL 1979 Opsonic specificity of human antibody to the type III polysaccharide of group B streptococcus. J Infect Dis 140:1004-1008

26. Anderson DC, Hughes BJ, Edwards MS, Buffone GJ, Baker CJ 1983 Impaired chemotaxigenesis by type III group B streptococci in neonatal sera: relationship to diminished concentrations of specific anticapsular antibody and abnormalities of serum complement. Pediatr Res 17:496-502

27. Linden V, Christensen KK, Christensen P 1983 Correlation between low levels of maternal IgG antibodies to R protein and neonatal septicemia with group B streptococci carrying R protein. Int Arch Allery Appl Immunol 71:168172

28. Christensen KK, Christensen P, Duc G, Hitzig WH, Linden V, Muller B, Seger RA 1984 Human IgG antibodies to carbohydrate and protein antigens in mouse protection tests with group B streptococci. Pediatr Res 18:478-482 